\title{
Supplementation of concentrate mixture on the production performance of kids during gestation period of doe
}

\author{
Ghimire SH ${ }^{1 *}$, DP Adhikari ${ }^{2}$, S Malla ${ }^{1}$, R Kadel $^{1}$ and RP Ghimire ${ }^{3}$
}

${ }^{1}$ Goat Research Station, Bandipur, Tanahun; ${ }^{2}$ National Cattle Research Program, Rampur, Chitwan; ${ }^{3}$ Pasture Forage Research Division, khumaltar, Lalitpur

\begin{abstract}
Supplementation of concentrate feed during late pregnancy of doe is an approach to improve milk yield and kid performance after kidding. The experiment was conducted to find out appropriate level and duration of supplementation to the pregnant doe. The data of the experiment were analyzed applying Completely Randomized Design (CRD) with factorial arrangements with three replications. First factor used in the experiment was the duration of concentrate feeding (15 days, 30 days, 45 days and 60 days) and second was amount of concentrate supplemented $(2.00 \%, 1.75 \%, 1.50 \%$ and $1.25 \%$ of their body weight). Birth weight, weaning weight, milk yield and kid mortality in different groups were recorded. Birth weight and weaning weight were found higher in 60 days supplemented group i.e. $2.3 \pm 0.23 \mathrm{~kg}$ and $10.94 \pm 0.41 \mathrm{~kg}$, respectively. Both birth weight and weaning weight were also found higher with 2 percent concentrate feeding group than others i.e. $2.1 \pm 0.23 \mathrm{~kg}$ and $9.64 \pm 0.42 \mathrm{~kg}$, respectively. Milk yield recorded for fourth week shows that higher milk yields were found in 2 percent concentrate supplemented group with 60 days time period. The result showed that by increasing the level of concentrate during late gestation period of does increased the birth weight, weaning weight of kids and increased milk yield of does. So the higher level of concentrate supplementation is required during 45 to 60 days of late gestation in does.
\end{abstract}

Key words: Weaning weight, birth weight, milk yield

\section{Introduction}

Goats are primarily raised for meat production in Nepal. Total meat production of Nepal in $2016 / 2017$ was 332,544 M.T. in which goat contribution is $20.33 \%(67,706$ M.T.) (DLS, 2018). Goats are found in all regions and are kept for meat purpose. Moreover different Governmental Organizations (GOs) and NonGovernmental Organizations (I/NGOs) are using the goat as a powerful poverty reduction tool in the rural areas. Goat farming is one of the rapidly growing enterprises in Nepal and plays significant role to increase the agricultural economy.

Goat is particularly important animal in subsistence agriculture farming system of Nepal because of its unique ability to adopt and maintain itself in harsh environment (Devendra et al., 1970). Likely, goats are multipurpose animal and potential source of meat, milk, hide, hair and manure. Goat meat is accepted by all ethnic groups and is important for some religious purpose.
On the other hand, the kid mortality reaches as high as 35\% (Pokharel et al., 2001) and one of the reasons is the poor lactating performance of doe due to the under nourishment during gestation period. Small amount of maize flour as supplement is provided during gestation and lactation period of does in rural areas. Therefore, it is likely that total protein supply is below than physiological requirements particularly during late gestation. Meat goats require a little more attention at least 4 to 6 weeks prior to the kidding. A good pasture, hay or silage as well as 227 gram to 453 gram of $12 \%$ protein grain mix is sufficient for that period (Solaiman, 2011). The birth weight of a kid on the other hand is associated positively with the nutrition of the doe, particularly the level of protein at late gestation period (Solaiman, 2011).

Pradhan (1979) suggested that poor feeding management during pregnancy period of doe's influences on birth weight of newly born kids. Therefore, if the plane of nutrition is increased for 4-6 weeks before kidding it results into low mortality of kids and heavier birth weight and

*Corresponding author: drshivahari@gmail.com 
also greater live weight gain of the kids that results heavier live weight of adult stocks. The steaming up is generally done in third phase of pregnancy i.e. during the last 60 days of pregnancy. This is important for building stores of nutrients for use in early lactation (Rangoma, 2011).

Therefore, this study undertakes effect of different levels of concentrate mixture supplementation during late period of gestation of goats to assess the appropriate level and duration of concentrate supplementation.

\section{Materials and Methods}

The experiment was carried out in the experimental crates of Goat Research Station, Bandipur, Tanahun. The experiment was conducted in Completely Randomized Design (CRD) with factorial arrangement $(4 \times 4)$ and replicated three times. The first factor was the duration of concentrate feeding (15 days, 30 days, 45 days and 60 days during late pregnancy) prior to kidding and second factor was amount of daily concentrate supplementation(i.e. $1.25 \%, 1.50 \%, 1.75 \%$ and $2.00 \%$ of their body weight). Animals with same breed and similar parity were selected for the experiment.

Deworming was done prior to the experiment with the Fenbendazole. Adaptation period of one week was carried out before starting the experiment. Data of daily feed intake and refusal, kidding size, kids' birth weight, and monthly weight, weaning weight and milk production of does from first week to fourth week were recorded.

The data was analyzed by using Analysis of Variance technique. GenStat Discovery Edition 4 (2013) and Microsoft Excel were used for the data analysis.

\section{Results and Discussion}

\section{Growth Performance of kids}

The effect on the growth rates of kids from birth to weaning weight due to the duration and level of concentrate supplementation are presented in Table 1. From the experiment, the doe's supplemented concentrate feed for 60 days of late gestation period had higher birth weight of kids than other shorter duration of supplementation. Birth weight of kids with different duration of supplementation were highly significant $(P<0.01)$. The birth weights of kids were $2.30 \pm 0.23,1.99 \pm 0.16,1.93 \pm 0.16$ and $1.53 \pm 0.23 \mathrm{~kg}$ for $60,45,30$ and 15 days supplementation periods, respectively. Similarly, first month weights of kids were also higher in 60 days duration $(5.50 \pm 0.19 \mathrm{~kg})$ followed by 45 days $(4.75 \pm 0.19 \mathrm{~kg}), 30$ days $(3.99 \pm 0.14 \mathrm{~kg})$ and 15 days $(3.61 \pm 0.19 \mathrm{~kg})$ and were highly significant. Similar trend was found in second, third and fourth months. In fourth months (weaning), the kids body weight for 60 days concentrate supplemented does was $10.94 \pm 0.41$ $\mathrm{kg}$ followed by 45 days $(9.63 \pm 0.44 \mathrm{~kg}), 30$ days $(8.38 \pm 0.38 \mathrm{~kg})$ and 15 days $(7.10 \pm 0.41 \mathrm{~kg})$ supplemented does. Growths of kids were highly significant $(P<0.01)$ form first to fourth month.

Birth weights of kids with 2 percent level of concentrate group were significantly higher $(P<0.05)$ than other level of concentrate group. Birth weight of kids were $2.10 \pm 0.23,2.00 \pm 0.16$, $1.75 \pm 0.16$ and $1.89 \pm 0.23 \mathrm{~kg}$ in $2.00 \% 1.75 \%$, $1.50 \%$ and $1.25 \%$ level of concentrate groups, respectively. In first and second month, weights of kids with different level of concentrate were significantly different $(P<0.05)$ and $2.00 \%$ concentrate level supplemented group had higher weight than other levels of supplementation. Weaning weight (four month weight) of kids with $2.00 \%$ levels of concentrate were $9.64 \pm 0.42 \mathrm{~kg}$ followed by $1.25 \%(9.00 \pm 0.40 \mathrm{~kg}), 1.75 \%$ $(8.60 \pm 0.42 \mathrm{~kg})$ and $1.50 \%(8.55 \pm 0.40 \mathrm{~kg})$. The growth rate of kids supplemented with different level of concentrates were significant at $P<0.05$ up to second months, and were non significant $(P>0.05)$ in third and fourth months. This might be due to the contribution of kids' trait in later stages and likely reduced doe's contribution.

Many studies have revealed that the higher rate of kid mortality and the post weaning weight of the kids are associated with its birth weight and level of feeding (Dhakal, 1995). Malau-Aduli et al. (2004) investigated the effect on Red Sokoto goat supplemented with crop residue and rations during third trimester of pregnancy. The author found that the goats supplemented with $2.00 \%$ level of conventional concentrate had higher birth weight $(1.40 \pm 0.16 \mathrm{~kg})$ followed by kids of those does supplemented with $2.00 \%$ of crop residue test ration $(1.34 \pm 0.16 \mathrm{~kg})$ and $1.00 \%$ of conventional ration $(1.30 \pm 0.16 \mathrm{~kg})$. Whereas three months weight of kids in the same experiment was highest in $2.00 \%$ level of conventional concentrate supplementation 
$(6.25 \pm 0.27 \mathrm{~kg})$ followed by $1.00 \%$ level of conventional concentrate $(5.54 \pm 0.27 \mathrm{~kg})$ and $2.00 \%$ of crop residue test ration $(5.33 \pm 0.27$ $\mathrm{kg})$. The author found that in control group (without supplementation), birth weight was $1.18 \pm 0.16 \mathrm{~kg}$ and third month weight was $4.16 \pm 0.27 \mathrm{~kg}$. The results of the author support the result of the present study. The similar result was obtained in a study in Bangladesh Agricultural University - Animal Nutrition Field Laboratory, where the average birth weight of kids in concentrate supplemented and nonsupplemented group were $1.45 \mathrm{~kg}$ and $0.85 \mathrm{~kg}$ respectively (Salim et al., 2002).From this study it is revealed that increment in level and duration of concentrate, results improvement in birth weight and weaning weight of kids. The interaction effects of duration and levels of concentrate supplementation to doe during late pregnancy in kids performance were similar $(P>0.05)$ from birth to four months.

Table 1. Growth performance of kids produced by the does supplemented with different level of concentrate for different duration prior to kidding.

\begin{tabular}{|c|c|c|c|c|c|}
\hline \multirow{2}{*}{$\begin{array}{l}\text { Duration * Feed \% } \\
\text { Duration }\end{array}$} & \multirow{2}{*}{$\begin{array}{c}\text { Birth wt } \\
\text { (kg) }\end{array}$} & \multicolumn{4}{|c|}{ Monthly weight (kg) } \\
\hline & & Wt1 & Wt2 & Wt3 & Wt4 \\
\hline 15 days & $1.53 \pm 0.23$ & $3.61 \pm 0.19$ & $5.53 \pm 0.39$ & $6.06 \pm 0.36$ & $7.10 \pm 0.41$ \\
\hline 30 days & $1.93 \pm 0.16$ & $3.99 \pm 0.14$ & $5.56 \pm 0.28$ & $6.63 \pm 0.33$ & $8.38 \pm 0.38$ \\
\hline 45 days & $1.99 \pm 0.16$ & $4.75 \pm 0.19$ & $6.55 \pm 0.39$ & $8.05 \pm 0.38$ & $9.63 \pm 0.44$ \\
\hline 60 days & $2.30 \pm 0.23$ & $5.50 \pm 0.19$ & $7.63 \pm 0.39$ & $10.00 \pm 0.36$ & $10.94 \pm 0.41$ \\
\hline F-cal & $<0.01$ & $<0.001$ & $<0.01$ & $<0.01$ & $<0.01$ \\
\hline LSD0.05 & 0.34 & 0.36 & 0.73 & 1.41 & 1.62 \\
\hline \multicolumn{6}{|c|}{ Feed quantity ( $\%$ body wt.) } \\
\hline 1.25 & $1.89 \pm 0.23$ & $4.33 \pm 0.19$ & $6.03 \pm 0.39$ & $7.58 \pm 0.35$ & $9.00 \pm 0.40$ \\
\hline 1.50 & $1.75 \pm 0.16$ & $4.34 \pm 0.19$ & $6.10 \pm 0.39$ & $7.55 \pm 0.35$ & $8.55 \pm 0.40$ \\
\hline 1.75 & $2.00 \pm 0.16$ & $4.34 \pm 0.14$ & $6.09 \pm 0.28$ & $7.32 \pm 0.36$ & $8.60 \pm 0.42$ \\
\hline 2.00 & $2.10 \pm 0.23$ & $4.70 \pm 0.19$ & $6.58 \pm 0.39$ & $8.05 \pm 0.36$ & $9.64 \pm 0.42$ \\
\hline F-cal & $<0.05$ & $<0.01$ & $<0.05$ & NS & NS \\
\hline LSD0.05 & 0.34 & 0.35 & 0.72 & 1.41 & 1.62 \\
\hline
\end{tabular}

NS = Non significant, LSD 0.05 = Least significant difference @ 5\%.

\section{Milk yield of Doe}

The milk yields of does supplemented with different level of concentrate for different duration are presented in Table 2 . The milk yield of does were highly significant $(P<0.01)$ from first to fourth week. From the experiment, milk yield of does supplemented for 45 days duration during late pregnancy had higher milk yield $(373.75 \pm 68.90 \mathrm{ml})$ followed by 60 days $(363.75 \pm 21.80 \mathrm{ml}), 15$ days $(225 \pm 32.80 \mathrm{ml})$ and 30 days $(147.5 \pm 8.29 \mathrm{ml})$ duration in first week. In second week, milk yield was higher in the group supplemented for 60 days duration followed by 45 days, 15 days and 30 days. Whereas, in third and fourth weeks, milk yield were higher in 60 days concentrate supplemented groups followed by 45 days, 30 days and 15 days, respectively.
Similarly, $2.00 \%$ concentrate supplementation group had higher milk yield $(338.75 \pm 68.20 \mathrm{ml})$ in comparison to $1.75 \%(311.25 \pm 82.90 \mathrm{ml}), 1.50 \%$ $(230 \pm 45.40 \mathrm{ml})$ and $1.25 \%(230 \pm 42.00 \mathrm{ml})$ in first week and were significantly different $(P<0.01)$. In second, third and fourth week, milk yield of does supplemented with $2.00 \%$ concentrate had higher milk yield followed by $1.75 \%, 1.25 \%$ and $1.50 \%$ supplemented group and were significantly different $(P<0.01)$ from first to fourth week. In a similar study in Nigeria by Malau-Aduli et al. (2004), $620 \pm 20 \mathrm{ml}, 480 \pm 20$ $\mathrm{ml}$ and $250 \pm 20 \mathrm{ml}$ of daily milk yield were found in $2.00 \%, 1.00 \%$ and $0 \%$ conventional concentrate supplementation during third trimester of pregnancy in Red Sokoto goats and were significantly different $(P<0.001)$. The finding of Malau-Aduli et al. (2004) supports this finding. Insufficient milk yield produce by doe is one of 
the causes of kid mortality among others. So, increasing the nursing capacity of doe through sufficient milk production to their kids may be one of the strategies for reducing kid mortality. In order to reduce the losses from kid mortality, concentrate supplementation with $2.00 \%$ of their body weight for 45 to 60 days duration during late pregnancy could be one of the better alternatives.

Table 2. Milk yields of does up to fourth week, supplemented with different level of concentrate for different duration prior to kidding.

\begin{tabular}{|c|c|c|c|c|}
\hline \multirow{2}{*}{$\begin{array}{l}\text { Duration of feeding and } \\
\text { feed quantity (\% body } \\
\text { wt.) } \\
\text { Duration } \\
\end{array}$} & \multicolumn{4}{|c|}{ Weekly milk production $\left(\mathrm{ml} \mathrm{day}{ }^{-1}\right)$} \\
\hline & Week1 & Week2 & Week3 & Week4 \\
\hline 15 days & $225 \pm 32.80$ & $163.75 \pm 24.80$ & $111.25 \pm 31.40$ & $132.50 \pm 21.70$ \\
\hline 30 days & $147.5 \pm 8.29$ & $151.25 \pm 25.90$ & $161.25 \pm 23.30$ & $176.25 \pm 9.66$ \\
\hline 45 days & $373.75 \pm 68.90$ & $277.5 \pm 34.00$ & $261.25 \pm 28.50$ & $253.75 \pm 31.10$ \\
\hline 60 days & $363.75 \pm 21.80$ & $320 \pm 25.20$ & $300 \pm 18.90$ & $300.00 \pm 17.40$ \\
\hline F-cal & $<0.01$ & $<0.01$ & $<0.01$ & $<0.01$ \\
\hline \multicolumn{5}{|c|}{ Feed quantity ( $\%$ body wt.) } \\
\hline 1.25 & $230 \pm 42.00$ & $201.25 \pm 44.30$ & $178.75 \pm 46.00$ & $197.50 \pm 36.10$ \\
\hline 1.50 & $230 \pm 45.40$ & $175 \pm 39.70$ & $176.25 \pm 45.80$ & $180.00 \pm 35.80$ \\
\hline 1.75 & $311.25 \pm 82.90$ & $248.75 \pm 40.50$ & $207.5 \pm 51.20$ & $226.25 \pm 46.00$ \\
\hline 2.00 & $338.75 \pm 68.20$ & $287.5 \pm 48.70$ & $271.25 \pm 39.00$ & $258.75 \pm 40.30$ \\
\hline F-cal & $<0.01$ & $<0.01$ & $<0.01$ & $<0.01$ \\
\hline
\end{tabular}

The interaction effect of durations of supplementation and different concentrate levels in case of milk yield of does up to fourth weeks is presented in Table 3. The interaction effect was significantly different $(P<0.01)$ in all weeks from first to fourth. Those does supplemented with $2.00 \%$ concentrate for 60 days had higher milk yield up to 4 weeks $(415 \pm 37.20,390 \pm 23.44$, $355 \pm 29.64,345 \pm 36.21 \mathrm{ml})$ than other groups followed by 45 days supplementation with $2.00 \%$ concentrate $(470 \pm 39.70, \quad 350 \pm 42.32, \quad 320 \pm$ $42.71,310 \pm 24.67 \mathrm{ml}$ ). Whereas, the does supplemented with $2.00 \%$ concentrate for 15 days had higher milk production $(310 \pm 22.55$, $220 \pm 31.73,200 \pm 40.20,190 \pm 22.42 \mathrm{ml})$ than those supplemented for 30 days $(160 \pm 32.62$, $190 \pm 24.22,210 \pm 22.67,190 \pm 23.80 \mathrm{ml}$ ) for the period of four weeks. But, in case of $1.75 \%$ concentrate supplemented group 45 days supplementation group $(510 \pm 39.70,350+42.32$, $320 \pm 42.71,310 \pm 24.67 \mathrm{ml}$ ) had higher milk yield followed by $2.00 \%, 1.50 \%$ and $1.25 \%$ for four weeks period. Similarly, in case of $1.50 \%$ and
$1.25 \%$ concentrate feed supplementation group higher milk yield for four weeks period was found in 60 days supplemented group followed by 45 days, 30 days and 15 days respectively.

Late pregnancy is the most critical stage of fetus development. At this stage, the fetus is developing its organs and also increasing in size, gaining $70 \%$ of its birth weight in later $6-8$ weeks of pregnancy. Rapid increase impinges on the size of the rumen. Good quality feeding is needed so that though feed intake is low it meets the requirements of the animal, because under nutrition causes low birth weight, low production of colostrums and reduction in milk production (Rangoma, 2011). It has direct effect on the growth and development of the kids and mortality as well. The present study also very close to the authors findings. 
Ghimire et al. (2019) Bang. J. Anim. Sci. 2019. 48 (1):23-28

Table 3. Interaction effect of level and duration of concentrate supplementation to the pregnant doe on weekly milk production.

\begin{tabular}{lccccc}
\hline Duration & $\begin{array}{l}\text { Feed quantity } \\
\text { (\% body wt.) }\end{array}$ & week1 & week2 & week3 & week4 \\
\cline { 2 - 5 } 15 days & 1.25 & $240 \pm 35.50$ & $175 \pm 39.21$ & $110 \pm 23.90$ & $140 \pm 19.45$ \\
& 1.5 & $160 \pm 41.23$ & $100 \pm 42.30$ & $60 \pm 28.06$ & $90 \pm 20.92$ \\
& 1.75 & $190 \pm 47.32$ & $160 \pm 46.41$ & $75 \pm 32.34$ & $110 \pm 23.63$ \\
& 2 & $310 \pm 22.55$ & $220 \pm 31.73$ & $200 \pm 40.20$ & $190 \pm 22.42$ \\
\hline \multirow{4}{*}{ days } & 1.25 & $125 \pm 26.44$ & $95 \pm 14.54$ & $100 \pm 19.66$ & $155 \pm 25.05$ \\
& 1.5 & $145 \pm 23.20$ & $120 \pm 21.20$ & $155 \pm 30.41$ & $165 \pm 30.20$ \\
& 1.75 & $160 \pm 30.00$ & $200 \pm 19.61$ & $180 \pm 24.33$ & $195 \pm 26.71$ \\
45 days & 2 & $160 \pm 32.62$ & $190 \pm 24.22$ & $210 \pm 22.67$ & $190 \pm 23.80$ \\
\hline & 1.25 & $225 \pm 17.32$ & $230 \pm 24.64$ & $210 \pm 28.00$ & $195 \pm 34.00$ \\
& 1.5 & $290 \pm 24.61$ & $210 \pm 40.21$ & $215 \pm 21.60$ & $205 \pm 32.19$ \\
& 1.75 & $510 \pm 26.33$ & $320 \pm 38.29$ & $300 \pm 39.60$ & $305 \pm 28.23$ \\
& 2 & $470 \pm 39.70$ & $350 \pm 42.32$ & $320 \pm 42.71$ & $310 \pm 24.67$ \\
\hline F-cal & 1.25 & $330 \pm 41.67$ & $305 \pm 29.60$ & $295 \pm 33.44$ & $300 \pm 24.14$ \\
& 1.5 & $325 \pm 32.62$ & $270 \pm 35.05$ & $275 \pm 40.45$ & $260 \pm 26.43$ \\
& 1.75 & $385 \pm 22.15$ & $315 \pm 30.26$ & $275 \pm 21.55$ & $295 \pm 39.90$ \\
& 2 & $415 \pm 37.20$ & $390 \pm 23.44$ & $355 \pm 29.64$ & $345 \pm 36.21$ \\
\hline
\end{tabular}

\section{Conclusion}

The study revealed that the higher amount of concentrate supplementation is required in late stage of gestation. Supplementation of $2.00 \%$ concentrate of their body weight (daily) during later 60 days of their gestation had resulted heavier body weight of the kids and higher milk yield. So, from the study, it is revealed one of the better strategies to reduce the kid mortality in goats. This combination increases the kidding size, birth weight of kids and milk yield of doe which leads to gain the better growth of kids as well as support to make healthy kids which ultimately decreases kid mortality in goats.

\section{References}

Anon (1989). Annual Report, Nepal Agricultural Research Council, Khumaltar, Lalitpur.

ARS (2067/068). Annual Report of Agriculture Research Station (Goat), Bandipur.

Devendra C and Burn M. (1970). Goat Production in the Tropics technical Communication $\mathrm{N}$. 19, Commonwealth Agricultural Bureau, Franham, Royal Bucks, England, Pp 184.
Dhakal K.P. (1995). Proposal for a Comprehensive Program on Animal Husbandry and Animal Health, Hills Leasehold Forestry and Forage Development Project, Project Working Paper 17.

DLS, 2018. Livestock Statistics of Nepal 2016/17. Department of Livestock Services, Statistics Section Hariharbhawan, Lalitpur, Nepal.

DLS, 2009/2010. Annual Report. Department of Livestock Services, Hariharbhawan, Lalitpur.

Malau-Aduli B. S., Eduvie L., Lakpini C., MalauAduli A. E. O. (2004). Crop-residue supplementation of pregnant does influences birth weight and weight gain of kids, daily milk yield but not the progesterone profile of Red Sokoto goats. Reprod. Nutr. Dev. 44

MOAC (2010). Statistical Information on Nepalese Agriculture 2009/10.

MOAD (2011). Statistical Information on Nepalese Agriculture 2010/11.

Pokharel P.K., Neopane S.P. and Aryal M.P. (2001). Selection impact on the productivity improvement of Goat (Capra hircus) in the hills of Nepal. Proceedings of the 4th National Animal Science Convention. 


\section{Concentrate supplementation in goat kid}

Pradhan S.L. (1979). Study on comparative performance of Sannen, Local Hill Goat and its crossbred with Jamunapari goat at Central Goat Farm, Bandipur. Nepalese J. Anim. Sci. $1: 35-45$.

Rangoma M. (2011). Feeding different categories of dairy goats.

Salim, H. M., Shahjalal M., Tareque A. M. M. and Kabir F. (2002). Effects of Concentrate
Supplementation on Growth and Reproductive Performance of Female Sheep and Goats under Grazing Condition. Pakistan Journal of Nutrition 1(4): 191-193, 2002. Pp 191-193.

Solaiman Sandra G. (2011); Feeding Management of a Meat Goat Herd; George Washington Carver, Agricultural Experiment Station, Tuskegee University, Tuskegee, Alabam. 